\title{
PENGARUH ASSET GROWTH, DIVIDEND PAYOUT RATIO (DPR) DAN PRICE EARNING RATIO (PER) TERHADAP RETURN SAHAM PADA LQ 45 DI BEI PERIODE 2015 - 2017
}

\author{
Natalia Ratna Ningrum \\ Fakultas Ekonomi, Universitas PGRI Yogyakarta \\ Email: natalia@upy.ac.id
}

\begin{abstract}
This research is to know about the Asset Growth, Dividend Payout Ratio, and Price Earning Ratio affects to Return Saham at LQ 45 in BEI Period 2015 - 2017. The objects in this research is companies that registered in LQ 45 group in BEI period 2015 - 2017. I'm using purposive sampling as the sampling technique, and regresi with SPSS for Windows program as the analyzing technique. The research result shows that the first Hypothesis is testing about the effect between Asset Growth to Stock Return and resulted value p-value 0,737 > 0,05 (no effect), so it can be concluded as $\mathrm{H}_{01}$ accepted $\left(\mathrm{H}_{1}\right.$ rejected). So the variable of Asset Growth is no affects Stock Return, and the second Hypothesis is testing about the effect of Dividend Payout Ratio to Stock Return and resulted the p-value 0,027 < 0,05 (significant), so it can be concluded as $\mathrm{H}_{02}$ rejected $\left(\mathrm{H}_{2}\right.$ accepted). So the variable of Dividend Payout Ratio is significantly affects Stock Return, and the third Hypothesis, Hypothesis is testing about the effect of Price Earning Ratio to Stock Return and resulted the p-value 0,122 <0,05 (no effect), so it can be concluded as $\mathrm{H}_{03}$ accepted $\left(\mathrm{H}_{3}\right.$ rejected). So the variable of Price Earning Ratio is no affects Stock Return, and by testing F simultaneously resulted value the significance level is 0,048 . Because the significance level $0,048<0,05$, so the zero hypothesis (Ho) is rejected. It means that Asset Growth, Dividend Payout Ratio and Price Earning Ratio affects significantly to Stock Return.
\end{abstract}

Keywords: Asset Growth, Dividend Payout Ratio, Price Earning Ratio and Stock Return.

\section{PENDAHULUAN}

Suatu investasi berkaitan dengan beberapa macam kegiatan, dalam investasi sejumlah dana pada aset teteap seperti tanah, mesin atau bangunan, ataupun aset finansial berupa deposito atau saham adalah merupakan kegiatan investasi yang sering dilakukan. Bagi beberapa investor yang mempunyai tipe berani dalam menanggung dan mengelola risiko, kegiatan investasi yang investor lakukan mencakup investari pada beberapa aset finansial yang lainnya dan lebih komplek seperti option, future dan warrants serta ekuitas international.

Teori keuangan menjelaskan bahwa bila risiko investasi meningkat maka tingkat keuntungan yang disyaratkan investor semakin besar. Untuk mengurangi kerugian atau risiko investasi maka investor dapat berinvestasi dalam berbagai jenis saham dengan membentuk portofolio. Sedangkan investor yang rasional melakukan keputusan investasi dimulai dengan menganalisis situasi saat ini, menyusun kebijakan investasi, mengimplikasikan strategi investasi, memonitor 
dan melakukan supervisi pada kinerja khusus para manajer keuangan dengan berbagai pertimbangan diidentifikasikan dengan penggunaan rasio keuangan atau variabel fundamental sebagai indikator dalam menganalisis suatu return saham.

Alasan dalam penggunaan beberapa variabel fundamental yaitu karena dalam studi literatur memberikan kesimpulan kurangnya penelitian yang mengkaitkan antara variabel return saham dengan beberapa faktor fundamental yang bisa dijelaskan. Di pihak lain sudah ada banyak penelitian yang dilakukan kurang meneliti tentang hubungan rasio keuangan terutama seperti Pertumbuhan Asset, Devidend Payout Ratio, Price Earning Ratio terhadap return saham. Beberapa alasan dikemukakan kurangnya penelitian yang berfokus pada pengaruh faktor fundamental terhadap return saham contohnya adalah masih adanya dugaan jika faktor tersebut kurang menjelaskan yang berarti dari return saham.

Hasil penelitian Luki Setiawan (2018) tentang Asset Growth tidak berpengaruh terhadap return saham, yaitu berdasarkan hasil penelitian tersebut disimpulkan bahwa Asset Growth mengalami suatu peningkatan tetapi tidak diikuti dengan adanya kenaikan return saham. Hal tersebut disebabkan karena suatu perusahaan yang sedang bertumbuh atau berkembang akan membutuhkan suatu biaya atau cost yang tinggi dibandingkan dengan perusahaan yang pertumbuhannya berada pada kondisi stabil atau tetap. Hasil penelitian Salimatul (2015) berpendapat bahwa Deviden Payout Ratio tidak berpengaruh terhadap return saham, berbeda dengan pendapat Michael Aldo Carlo (2014) hasil penelitiannya tentang Deviden Payout Ratio berpengaruh positif dan signifikan terhadap return saham, sedangkan untuk variabel Price Earning Ratio menurut I Made Januar Antara (2012) hasil penelitiannya bahwa Price Earning Ratio berpengaruh negatif terhadap return saham berbeda dengan hasil penelitian Michael Aldo Carlo (2014) bahwa Price Earing Ratio tidak berpengaruh terhadap return saham. Dari beberapa jurnal tersebut maka penulis mencoba untuk lebih mengembangkan berbagai jurnal tersebut.

Dalam melakukan investasi di pasar modal, para investor memiliki persepsi yang berbeda-beda terhadap variabel-variabel penentu yang dapat mempengaruhi return saham sebagai bahan pertimbangan dalam melakukan investasi. Suatu informasi keuangan adalah informasi yang berhubungan dengan kondisi keuangan suatu perusahaan yang umumnya ditunjukkan dalam sebuah laporan keuangan yang merupakan salah satu ukuran kinerja suatu perusahaan. Informasi keuangan sering digunakan untuk memprediksi return saham.

Penelitian ini pada dasarnya merupakan kelanjutan dari penelitianpenelitian yang telah dilakukan sebelumnya; fokus dari penelitian ini adalah mendesain suatu pengaruh Asset Growth, Dividen Payout Ratio dan Price Earning Ratio terhadap Return Saham pada LQ45 di BEI tahun 2015 - 2017. Perbedaannya terletak pada periode pengamatan dan dasar pemilihan saham yang terpilih.

\section{METODE PENELITIAN}

Pada penelitian ini dilakukan di BEI untuk memperoleh data keuangan dari perusahan LQ45 Waktu penelitian yang dilakukan dalam penelitan adalah 3 tahun, yaitu laporan keuangan pada 31 Januari 2015 samapai dengan 31 Desember 
2017. Dalam penelitian ini, maka metodelogi yang digunakan adalah metodologi kuantitatif. Penulis melakukan penelitian dan pengamatan, yaitu pada hubungan pengaruh Asset Growth, Dividend Payout Ratio dan Price Earning Ratio terhadap Return Saham. Variable Independen (dalam hal ini variabel X) Dalam penelitian ini terhadap tiga variabel independen $(\mathrm{X})$ yaitu Asset Growth, Price Earning Ratio (PER) dan Deviden Payout Ratio (DPR). Asset Growth dihitung dengan menggunakan estimasi pertumbuhan yaitu total aktiva tahun tersebut dikurangi total aktiva tahun sebelumnya dibagi dengan total aktiva tahun sebelumnya. Deviden Payout Ratio adalah dihitung dengan cara membagi dividen per share dengan Earning per share. Price Earning Ratio (PER) adalah menghitung dengan cara membagi harga pasar saham dengan laba per lembar saham. Variabel Dependen (dalam hal Y) adalah Return Saham. Return Saham adalah suatu total dalm investasi dengan menjumlahkan indikator yield dan capital gain yang diperoleh dari suatu investasi.

Populasi adalah kumpulan dari seluruh individual atau item yang diteliti yang memiliki berbagai karakteristik Obyek dalam penulisan penelitian ini adalah perusahaan yang sahamnya terdaftar dalam LQ45 di BEI periode 2015 - 2017. Jenis data yang digunakan dalam penelitian ini adalah data sekunder yang sumber datanya berasal dari Indonesia Stock Exchange (IDX) untuk periode pengamatan Januari 2015 s/d Desember 2017 secara bulanan.

Pada penelitian ini teknik yang digunakan dalam pengambilan sampel adalah purposive sampling, yaitu teknik penentuan tertentu. Perusahaan yang menjadi sampel pada penelitian ini adalah perusahaan yang memiliki kriteria Perusahaan yang telah terdaftar dalam LQ45 di Bursa Efek Indonesia tanggal 1 Januari 2015 sampai tanggal 31 Desember 2017 dan mengeluarkan laporan keuangan audit tahun 2015 - 2017.

Dalam menganalisis pengaruh suatu variabel independen terhadap variabel dependen menggunakan model analisis regresi linear berganda. Model tersebut dipiiih karena penelitian ini dirancang untuk meneliti beberapa variabel-variabel bebas yang berpengaruh terhadap variabel terikat dengan penggunaan pooling (pooled times series). Bentuk umum dari perumusan model regresi linear berganda menurut Setiawan $(2010,61)$ adalah :

$$
\mathrm{Y}=\beta_{0}+\beta_{1} X 1+\beta_{2} X 2+\beta_{3} X 3+\varepsilon
$$

Dalam melakukan analisis regresi linear berganda mensyaratkan pemenuhan beberapa asumsi klasik Gauss-Markov. Jika asumsi ini dipenuhi, maka parameter yang diperoleh adalah bersifat BLUE (Best Linear Unbiased Estintator) (Ariefianto, 2012, 26). berikut:

Suatu model dikatakan BLUE apabila memenuhi persyaratan sebagai

\section{1) Uji Normalitas Data}

Uji normalitas data bertujuan untuk menguji apakah dalam model regresi. variabel dependen dan variabel independen mempunyai distribusi normal atau tidak. Model regresi yang baik adalah memiliki distribusi data norrnal atau mendekati normal. Uji normalitas dapat dilakukan dengan menggunakan One 
Sample Kolynogorov-Smirnov dimana normalitas data dapat dideteksi dengan melihat angka signifikansi. Kriteria pengujiannya adalah sebagai berikut:

a) Jika angka signifikansi lebih besar dari alpha $(0,05)$, maka data berdistribusi normal.

b) Jika, angka signifikansi lebih kecil dari alpha (0.05). maka data tidak berdistribusi normal. Uji normalitas data dalam penelitian ini menggunakan uji One Sample Kohnogorov-Smirnov dengan tingkat signifikansi $5 \%$.

\section{2) Uji Multikolinearitas}

Uji Multikolinearitas dapat dideteksi dengan menganalisis beberapa matrik korelasi antar variabel bebas dan perhitungan suatu nilai tolerance dan VIF. Dari kedua ukuran tersebut dapat ditunjukkan setiap variabel bebas manakah yang akan dijelaskan oleh variabel bebas lainnya. Tolerance mengukur suatu variabilitas variabel bebas yang terpilih yang tidak dapat dijelaskan oleh variabel bebas lainnya. Jadi nilai suatu tolerance yang rendah sama dengan nilai VIF yang tinggi (karena $\mathrm{VIF}=1 /$ tolerance) dan menunjukkan adanya kolinearitas yang tinggi. Nilai cut off yang sering dipakai adalah nilai tolerance 0,10 atau sama dengan VIF diatas 10. Pengaruh multikolinearitas dapat juga dilihat dari suatu tolerance dan lawannya Variance Inflation Factor (VIF).

\section{3) Uji Autokorelasi}

Satu asumsi penting dari model linear klasik adalah bahwa kesalahan yang masuk kedalam fungsi regresi populasi adalah random atau tidak berkorelasi. jika asumsi ini dilanggar, maka analisis akan mempunyai problem serial korelasi atau autokorelasi. Pengujian ada tidaknya autokorelasi dalarn persamaan regresi dapat dilakukan dengan melihat nilai DW (Durbin Watson).

\section{4) Uji Heteroskedastisitas}

Uji heteroskedastisitas digunakan untuk melihat apakah terdapat ketidaksamaan varians dari residual satu pengamatan ke pengamatan yang lain. Model regresi yang memenuhi persyaratan ditunjukkan dengan adanya kesamaan varians dari residual satu pengamatan ke pengamatan yang lain tetap atau disebut homoskedastisitas.

Dalam penelitian ini uji heteroskedastisitas menggunakan uji rank spearman dengan kriteria sebagai berikut (Santoso dalam Susilohadi 2010):

a) Jika p-value (sig) lebih besar dari alpha $(0,05)$, maka dikatakan bahwa data tidak ada masalah heteroskedastisitas.

b) Jika p-value (sig) lebih kecil dari alpha $(0,05)$, maka dikatakan bahwa data ada masalah heteroskedastisitas.

\section{Hipotesis Statistik}

\section{a. Uji t}

Hipotesis 1

$\mathrm{H}_{01}: \beta_{1}=0$ (Asset Growth tidak berpengaruh signifikan terhadap Return Saham) 
$\mathrm{H}_{\mathrm{a} 1}: \beta_{1} \neq 0$ (Asset Growth berpengaruh signifikan terhadap Return Saham)

Dengan meningkatnya Growth berarti kinerja perusahaan semakin baik dan sebagai dampaknya harga saham perusahaan juga semakin meningkat. Dengan meningkatnya harga saham maka return saham perusahaan yang bersangkutan juga meningkat. Demikian juga sebaliknya.

Hipotesis 2

$\mathrm{H}_{02}: \beta_{2}=0$ (PER tidak berpengaruh signifikan terhadap Return Saham)

$\mathrm{H}_{\mathrm{a} 2}: \beta_{2} \neq 0$ (PER berpengaruh signifikan terhadap Return Saham)

Price Earning Ratio (PER) merupakan salah satu dari ratio pasar yang digunakan untuk memprediksi return saham, dimana jika semakin tinggi PER maka semakin tinggi pula harga perlembar saham suatu perusahaan, sehingga saham perusahaan tersebut termasuk saham yang blue chip dalam pasar modal

Hipotesis 3

$\mathrm{H}_{03}: \beta_{3}=0$ (Dividend Payout Ratio tidak berpengaruh signifikan terhadap Return saham)

$\mathrm{H}_{\mathrm{a} 3}: \beta_{3} \neq 0$ (Dividend Payout Ratio berpengaruh signifikan terhadap Return Saham)

Dividend Payout Ratio memperkirakan return saham dengan beberapa keberhasilan yang diharapkan, seperti salah satunya adalah mengenai pertumbuhan dividen dan hasil penelitiannya yang menyatakan bahwa terdapat pengaruh yang signifikan dividend payout ratio terhadap return saham suatu perusahaan.

Kriteria :

Signifikan $<0.05$ dan signifikan $>0.05$

Ho diterima jika : $-\mathrm{t}_{\text {tabel }} \leq \mathrm{t}_{\text {hitung }} \leq \mathrm{t}_{\text {tabel }}$

Ho ditolak jika : $t_{\text {hitung }}>t_{\text {tabel }}$ atau -- $t_{\text {hitung }}<--t_{\text {tabel }}$

\section{b. Uji F}

Uji F dipakai untuk melihat seberapa pengaruh variabel-variabel independen secara keseluruhan terhadap suatu variabel dependen. Pengujian ini dilakukan dengan cara membandingkan nilai $\mathrm{F}_{\text {hitung }}$ dengan $\mathrm{F}_{\text {tabel. }}$. Penetapan suatu hipotesis yang akan diuji dalam penelitian ini adalah sebagai berikut:

Hipotesis 4

$\mathrm{H}_{04}: \beta_{1}=\beta_{2}=\beta_{3}=0$ (Asset Growth, Price Earning Ratio (PER) dan Devidend Payout Ratio (DPR) secara bersama-sama tidak berpengaruh signifikan terhadap Return Saham)

$\mathrm{H}_{\mathrm{a} 4} \quad: \beta_{1} \neq \beta_{2} \neq \beta_{3} \neq 0$ (Asset Growth, PER dan DPR secara bersama-sama berpengaruh signifikan terhadap Return Saham).

Asset Growth, PER dan DPR dan ERB searah dan linear, artinya semakin besar Return Saham yang diharapkan, maka semakin besar pula Asset Growth, PER dan DPR yang ditanggung.

Kriteria :

Signifikan $<0.05$ dan signifikan $>0.05$

$\mathrm{F}_{\text {hitung }}<\mathrm{F}_{\text {tabel }} \longrightarrow$ Ho diterima

$\mathrm{F}_{\text {hitune }}>\mathrm{F}_{\text {tabel }} \longrightarrow$ Ho ditolak 


\section{c. Adjusted $\mathbf{R}^{2}$ (koefisien Determinasi)}

Adjusted $\mathrm{R}^{2}$ digunakan adalah untuk menguji suatu ketepatan model dengan mencari koefisien determinasi yang menyatakan ada berapa proporsi oleh variabel bebas yang dimasukkan dalam model tersebut.

Nilai Adjusted $\mathrm{R}^{2}$ mempuyai interval antara 0 sampai $1\left(0<\mathrm{R}^{2}<1\right)$, semakin besar Adjusted $\mathrm{R}^{2}$ dan mendekati 1, semakin baik hasil untuk model regresi tersebut dan dapat dikatakan bahwa jika pengaruh variabel bebas semakin kuat dalam menjelaskan variabel terikat tersebut. Sebaliknya jika semakin mendekati 0, maka variabel independen secara keseluruhan tidak dapat menjelaskan variabel dependen.

\section{ANALISA DAN PEMBAHASAN}

Asumsi Normalitas.

\begin{tabular}{llr} 
& One-Sample Kolmogorov-Smirnov Test & Unstandardized Residual \\
$N$ & & 129 \\
Normal Parameters & \\
& & Mean \\
Most Extreme & Std. Deviation & .0000000 \\
Differences & Absolute & 1.82967870 \\
& Positive & .116 \\
Kolmogorov-Smirnov Z & Negative & .116 \\
Asymp. Sig. (2-tailed) & & -.086 \\
a. Test distribution is Normal. & 1.321 \\
\hline
\end{tabular}

Berdasarkan table output SPSS tersebut, diketahui bahwa nilai signifikansi asymp. Sig. (2-tailed) sebesar 0,061 lebih besar dari 0,05. Maka data berdistribusi normal.

Asumsi Heteroskedastisitas

\begin{tabular}{|c|c|c|c|c|c|c|}
\hline & \multirow{3}{*}{ Model } & & Coefficien & \multirow{3}{*}{$\begin{array}{c}\text { Standardize } \\
d \\
\text { Coefficients } \\
\text { Beta }\end{array}$} & & \multirow{3}{*}{ Sig. } \\
\hline & & \multicolumn{2}{|c|}{$\begin{array}{l}\text { Unstandardized } \\
\text { Coefficients }\end{array}$} & & \multirow[b]{3}{*}{10.082} & \\
\hline \multirow{6}{*}{1} & & $B$ & Std. Error & & & \\
\hline & (Constant) & 1.486 & .147 & & & .000 \\
\hline & Aset Growth & -.004 & .005 & -.078 & -.846 & .399 \\
\hline & DPR & .000 & .001 & -.062 & -.675 & .501 \\
\hline & PER & $-7.970 \mathrm{E}-5$ & .000 & -.106 & -1.193 & .235 \\
\hline & a. Dependent & iable: ABS_ & & & & \\
\hline
\end{tabular}

Hasil diatas menunjukkan bahwa semua variabel Asset Growth, Dividend Payout Ratio, dan Price Earning Ratio memenuhi asumsi homogen. Hal ini disebabkan nilai sign keempat variabel tersebut $>$ Alpha 5\% $($ Sign $>0,05)$. 
Asumsi Bebas Multikolinier dan Bebas Autokorelasi

\begin{tabular}{|c|c|c|c|c|c|}
\hline \multicolumn{6}{|c|}{ Model Summary ${ }^{\circ}$} \\
\hline Model & $\mathrm{R}$ & R Square & $\begin{array}{l}\text { Adjusted R } \\
\text { Square }\end{array}$ & $\begin{array}{l}\text { Std. Error of the } \\
\text { Estimate }\end{array}$ & Durbin-Watson \\
\hline 1 & $.247^{\mathrm{a}}$ & .061 & .038 & 1.85150 & 2.055 \\
\hline \multicolumn{6}{|c|}{ a. Predictors: (Constant), PER, DPR, Aset Growth } \\
\hline \multicolumn{6}{|c|}{ b. Dependent Variable: Return Saham } \\
\hline
\end{tabular}

Nilai dU dan dL untuk $\mathrm{k}=3 \mathrm{n}=128$

$\mathrm{dU}=1,7596 ; \mathrm{dL}=1,6638$ maka $4-\mathrm{dU}=2,2404$

diperoleh nilai DW $=2,055$ terletak antara 1,7596 dan 2,2404 sehingga

disimpulkan tidak terjadi autokorelasi.

\section{Uji Multikolinieritas}

\begin{tabular}{|c|c|c|c|c|c|c|c|c|}
\hline & \multirow{2}{*}{ Model } & $\begin{array}{r}\text { Unsta } \\
\text { Coe }\end{array}$ & $\begin{array}{l}\text { dardized } \\
\text { icients }\end{array}$ & $\begin{array}{l}\text { Coefficients }^{\mathrm{a}} \\
\text { Standardized } \\
\text { Coefficients }\end{array}$ & \multirow{2}{*}{$\mathrm{t}$} & \multirow{2}{*}{ Sig. } & \multicolumn{2}{|c|}{$\begin{array}{c}\text { Collinearity } \\
\text { Statistics }\end{array}$} \\
\hline & & B & Std. Error & Beta & & & $\begin{array}{c}\text { Toleranc } \\
\mathrm{e}\end{array}$ & VIF \\
\hline \multirow{3}{*}{1} & (Constant) & 2.245 & .227 & & 9.895 & .000 & & \\
\hline & $\begin{array}{l}\text { Aset } \\
\text { Growth }\end{array}$ & -.003 & .008 & -.030 & -.337 & .737 & .937 & 1.067 \\
\hline & $\begin{array}{l}\text { DPR } \\
\text { PER }\end{array}$ & $\begin{array}{l}.005 \\
.000\end{array}$ & $\begin{array}{l}.002 \\
.000\end{array}$ & $\begin{array}{l}.201 \\
.135\end{array}$ & $\begin{array}{l}2.243 \\
1.555\end{array}$ & $\begin{array}{l}.027 \\
.122\end{array}$ & $\begin{array}{l}.938 \\
.997\end{array}$ & $\begin{array}{l}1.066 \\
1.004\end{array}$ \\
\hline \multicolumn{4}{|c|}{ a. Dependent Variable: Return Saham } & & & & & \\
\hline
\end{tabular}

Jika nilai tolerance $>0,10$ dan VIF $<10,00$ disimpulkan tidak terjadi multikolinieritas.

Berdasarkan output SPSS diperoleh nilai tolerance $>0,10$ dan VIF $<10,00$ maka dapat disimpulkan tidak terjadi multikolinieritas.

\section{Pengujian Hipotesis}

a. Uji t

\begin{tabular}{|c|c|c|c|c|c|c|}
\hline \multicolumn{7}{|c|}{ Coefficients $^{\mathrm{a}}$} \\
\hline & \multirow{2}{*}{ Model } & \multicolumn{2}{|c|}{ Unstandardized Coefficients } & $\begin{array}{l}\text { Standardized } \\
\text { Coefficients }\end{array}$ & $t$ & $\mathrm{Sia}$ \\
\hline \multirow{5}{*}{1} & & B & Std. Error & Beta & & \\
\hline & (Constant) & 2.245 & .227 & & 9.895 & .000 \\
\hline & Aset Growth & -.003 & .008 & -.030 & \multirow{4}{*}{$\begin{array}{l}-.337 \\
2.243 \\
1.555\end{array}$} & .737 \\
\hline & DPR & .005 & .002 & .201 & & .027 \\
\hline & PER & .000 & .000 & .135 & & .122 \\
\hline & \multicolumn{3}{|c|}{ a. Dependent Variable: Return Saham } & & & \\
\hline
\end{tabular}

a) Hasil Pengujian Hipotesis 1

Hipotesis pertama menguji pengaruh antara Asset Growth terhadap Return Saham.

$\mathrm{H}_{01}: \beta_{1}=0$ (Asset Growth tidak berpengaruh signifikan terhadap Return Saham)

$\mathrm{H}_{1}: \beta_{1} \neq 0$ (Asset Growth berpengaruh signifikan terhadap Return Saham) Dari tabel diatas, diperoleh nilai p-valuenya 0,737 maka dapat disimpulkan bahwa $\mathrm{H}_{01}$ diterima atau tidak signifikan karena nilai sig.

Bisman (Bisnis \& Manajemen): The Journal Of Business and Management 
$0,737>0,05$ berarti tidak ada pengaruh Aset Growth terhadap return saham.

b) Hasil Pengujian Hipotesis 2

Hipotesis kedua menguji pengaruh antara Dividend Payout Ratio terhadap Return Saham.

$\mathrm{H}_{02}: \beta_{2}=0$ (Dividend Payout Ratio tidak berpengaruh signifikan terhadap Return Saham)

$\mathrm{H}_{2}: \beta_{2} \neq 0$ (Dividend Payout Ratio berpengaruh signifikan terhadap Return Saham) Dari tabel diatas, nilai p-valuenya 0,027, maka dapat disimpulkan bahwa $\mathrm{H}_{2}$ diterima atau signifikan karena nilai sig. 0,027 < 0,05 berarti terdapat pengaruh DPR terhadap return saham.

c) Hasil Pengujian Hipotesis 3

Hipotesis ketiga menguji pengaruh antara Price Earning Ratio terhadap Return Saham.

$\mathrm{H}_{03}: \beta_{3}=0$ (Price Earning Ratio tidak berpengaruh signifikan terhadap Return Saham)

$\mathrm{H}_{3}: \beta_{3} \neq 0$ (Price Earning Ratio berpengaruh signifikan terhadap Return Saham)

Dari tabel diatas, diperoleh nilai p-valuenya 0,122 , maka dapat disimpulkan bahwa $\mathrm{H}_{03}$ diterima atau tidak signifikan karena nilai sig. $0,122>0,05$ berarti tidak ada pengaruh PER terhadap return saham.

\section{b. Uji F (F-Test)}

Pengujian signifikansi secara simultan (bersama-sama) dilakukan dengan menggunakan uji $\mathrm{F}$ untuk mengetahui pengaruh dari variabelvariabel independen yaitu Asset Growth, Dividend Payout Ratio dan Price Earning Ratio secara bersama-sama terhadap Return Saham. Hasil pengujian F-Test sebagaimana tercantum dalam tabel dibawah ini.

\section{Tabel 4.9}

ANOVA

\begin{tabular}{|c|c|c|c|c|c|c|}
\hline \multicolumn{7}{|c|}{ ANOVA $^{\circ}$} \\
\hline & Model & Sum of Squares & $d f$ & $\begin{array}{l}\text { Mean } \\
\text { Square }\end{array}$ & $F$ & Sig. \\
\hline \multirow{3}{*}{1} & Regression & 27.835 & 3 & 9.278 & 2.707 & $.048^{a}$ \\
\hline & Residual & 428.509 & 125 & 3.428 & & \\
\hline & Total & 456.344 & 128 & & & \\
\hline
\end{tabular}

Berdasarkan perhitungan diperoleh hasil nilai tingkat signifikasi sebesar 0,048. Tingkat signifikansi 0,048 $<0,05$, maka hipotesis nol (Ho) ditolak. Ini berarti bahwa Asset Growth, Dividend Payout Ratio dan Price Earning Ratio (PER) secara bersama - sama berpengaruh signifikan terhadap Return Saham.

\section{c. Uji Koefisien Determinasi $\left(\mathbf{R}^{2}\right)$}

Koefisien determinasi atau Adjusted $\mathrm{R}^{2}$ adalah suatu besaran yang menjelaskan proporsi variabel dependen yaitu Return Saham, yang dijelaskan oleh beberapa 
variabel-variabel independen Asset Growth, Dividend Payout Ratio dan Price Earning Ratio.

Hasil perhitungan uji koefisien determinasi dapat dilihat pada tabel di bawah ini.

Tabel 4.10

\begin{tabular}{|c|c|c|c|c|}
\hline \multicolumn{5}{|c|}{ Model Summary } \\
\hline Model & $\mathrm{R}$ & R Square & $\begin{array}{l}\text { Adjusted R } \\
\text { Square }\end{array}$ & $\begin{array}{l}\text { Std. Error of the } \\
\text { Estimate }\end{array}$ \\
\hline 1 & $\begin{array}{l}.247^{\mathrm{a}} \\
\text { a. Predictc }\end{array}$ & :061 & ER, DPR, Ase & 1.85150 \\
\hline
\end{tabular}

Berdasarkan perhitungan regresi, nilai koefisien determinasi (adjusted $\mathrm{R}^{2}$ ) yang diperoleh sebesar 0,038 . Ini berarti bahwa dalam penelitian ini menunjukkan terdapat korelasi antara Asset Growth, Dividend Payout Ratio (DPR) dan Price Earning Ratio (PER) terhadap Return Saham. Sedangkan untuk koefisien determinasinya (Adjusted R Square) sebesar 0,038, hal ini menunjukkan bahwa kemampuan variabel Asset Growth, Dividend Payout Ratio dan Price Earning Ratio mempengaruhi naik turunnya nilai Return Saham adalah sebesar 3,8 \% dan terdapat variabel lain yang dapat berpengaruh terhadap return saham kecuali tiga variabel diatas.

\section{Pembahasan Hasil Penelitian}

\section{a. Analisis pengaruh Asset Growth terhadap Return Saham}

Assets Growth tidak berpengaruh terhadap Return Saham. Hal tersebut menunjukkan bahwa kenaikan Assets Growth akan menurunkan suatu return saham yang dimiliki oleh investor. Jika kenaikan aktiva yang berasal dari kenaikan laba dan bukan dari kenaikan berasal dari kenaikan hutang maka akan mengindikasikan keberhasilan perluasan yang akan dilakukan oleh perusahaan. Semakin berhasilnya perluasan yang dilakukan oleh perusahaan maka akan semakin banyak biaya yang akan dikeluarkan oleh perusahaan yang nantinya akan mengurangi return dari saham yang dimiliki oleh investor.

Tingkat pertumbuhan aktiva yang cepat mengindikasikan adanya ekspansi yang dilakukan oleh perusahaan, semakin besar dana yang dibutuhkan perusahaan maka akan semakin besar pula laba yang ditahan oleh perusahaan maka akan semakin kecil deviden yang akan dibagikan untuk para pemegang saham. Hasil penelitian ini sejalan dengan penelitian yang dilakukan oleh Luki Setiawan Djajadi dan Gerianta Wirawan Yasa (2018) sehingga investor akan lebih menyukai perusahaan yang memiliki tingak assets growth yang lebih rendah.

\section{b. Analisis pengaruh Dividend Payout Ratio (DPR) terhadap Return Saham.}

Berkaitan dengan dividend sangat penting karena merupakan salah satu dari indikator yang digunakan oleh investor dalam menganalisis prospek suatu perusahaan dengan melihat suatu kebijakan dividen dalam perusahaan tersebut. Seorang investor akan beranggapan apabila perusahaan selalu akan meningkatkan dividen maka perusahaan tersebut dianggap sedang dalam keadaan baik dan sebaliknya jika semakin tinggi dividen payout ratio semakin kecil akan merugikan 
investor (para pemegang saham) tetapi internal financial perusahaan semakin kuat.

Dividend Payout Ratio memberikan suatu alasan rasional bahwa perusahaan -perusahaan sunkan untuk menurunkan dividen. Jika perusahaan memotong dividen, maka investor akan menganggap sinyal buruk karena dianggap perusahaan tersebut membutuhkan dana jadi untuk perusahaan yang mempunyai return saham tinggi, probabilitas untuk mengalami suatu laba yang menurun adalah tinggi. Alasan lain juga menyatakan bahwa pembayaran dividen dianggap lebih kecil risikonya dibanding capital gains. Dengan demikian, perusahaan yang membayar rasio dividen yang tinggi akan mempunyai mempunyai nilai saham yang tinggi yang akan berimbas pada return saham yang diterima oleh investor. Penelitian ini sejalan dengan Michael Aldo Carlo (2014), tetapi beberapa peneliti tidak sejalan dengan penelitian ini bahwa Dividend Payout Ratio tidak berpengaruh signifikan terhadap return saham ditunjukkan dari hasil penelitian Salimatul Musyarofah, Suhadak dan Raden Rustam Hidayat (2015).

c. Analisis pengaruh Price Earning Ratio (PER) terhadap Return Saham

Kerap kali nilai Price Earning Ratio yang tinggi menunjukkan bahwa investor akan bersedia membayar saham dengan harga yang tinggi dengan harapan meningkatnya laba perusahaan dimasa yang akan datang maka akan semakin tinggi sehingga dividen yang akan dibayarkan juga tinggi. Sehingga investor memiliki harapan yang tinggi pada suatu saham dalam perusahaan tersebut. Hal ini disebabkan oleh berbagai macam faktor, seperti politik, ekonomi dan kondisi sosial di negara Indonesia yang tidak selalu stabil, jadi nilai harga saham yang ada tidak berdasarkan informasi mengenai kondisi perusahaan tetapi dipengaruhi oleh permintaan (demand) dan penawaran (supply) akan harga saham (Jauhari, 2003). Penelitian ini sejalan dengan Michael Aldo Carlo (2014), Jauhari (2003),dan Lestari (2012) yang menyatakan bahwa Price Earning Ratio tidak berpengaruh terhadap return saham. Berbeda dengan penelitian yang dilakukan oleh I Made Januari Antara (2012) yang tidak sejalan dengan penelitian ini, yang menyatakan bahwa Price Earning Ratio berpengaruh signifikan terhadap return saham.

\section{d. Analisis pengaruh Asset Growth, Dividend Payout Ratio (DPR), dan Price Earning Ratio (PER) terhadap Return Saham}

Hasil perhitungan uji secara bersama-sama menunjukkan bahwa variabel Asset Growth, Dividend Payout Ratio (DPR), dan Price Earning Ratio (PER) berpengaruh signifikan terhadap Variabel Return Saham. Ini ditunjukkan sig valuenya lebih kecil dari tingkat signifikannya 0,048<0,05. Oleh karena itu Asset Growth, Dividend Payout Ratio (DPR) dan Price Earning Ratio (PER) dapat menjadi pertimbangan secara bersama-sama bagi para investor dalam menentukan seberapa besar tingkat return saham dalam arti lain dapat dikatakan bahwa Return Saham dipengaruhi oleh Asset Growth, Dividend Payout Ratio (DPR) dan Price Earning Ratio (PER). 


\section{PENUTUP}

\section{Simpulan}

Berdasarkan hasil penelitian dan analisis statistik yang telah dilakukan, maka dapat diambil simpulan bahwa variabel Asset Growth secara parsial tidak berpengaruh signifikan terhadap Return Saham, dengan demikian hipotesis penelitian tidak terbukti. Variabel Dividend Payout Ratio (DPR) secara parsial berpengaruh signifikan terhadap Return Saham, dengan demikian hipotesis penelitian terbukti. Variabel Price Earning Ratio (PER) secara parsial tidak berpengaruh signifikan terhadap Return Saham, dengan demikian hipotesis penelitian ini tidak terbukti. Variabel Asset Growth, Dividend Payout Ratio (DPR) dan Price Earning Ratio (PER) secara bersama - sama berpengaruh signifikan terhadap Return Saham, dengan demikian hipotesis penelitian ini terbukti.

\section{Saran}

Saran yang dapat diberikan oleh peneliti untuk penelitian yang akan datang adalah penelitian selanjutnya sebaiknya menggunakan sampel yang lebih banyak agar lebih terlihat pengaruhnya yang signifikan, penelitian selanjutnya sebaiknya menggunakan periode penelitian yang yang jangka waktunya lebih panjang serta penelitian selanjutnya sebaiknya menggunakan variabel-variabel bebas yang lainnya yang diduga dapat berpengaruh signifikan juga terhadap Return Saham seperti contohnya rasio-rasio keungan yang lainnya yang belum diteliti oleh penelitian tersebut diatas. 


\section{DAFTAR PUSTAKA}

Antara Januari, 2013. Pengaruh Dividend Payout Ratio, Price To Book Value Ratio dan Price To Earning Ratio pada Return Saham di Bursa Efek Indonesia Periode 2009 - 2011.

Anaroga, 2006. Fundamentals of Financial Management, Tenth Edition, Precentice-Hall Int, Inc, New Jersey.

Auliyah Robiatul, Hamzah Ardi, 2006. Analisis Karakteristik Perusahaan, Industri dan Ekonomi Makro Terhadap Return Dan Beta Saham Syariah.

Brigham, Eugene F, Houston, Joel F, 2009. Fundamental of Financial Management, Edisi kesepuluh, Penerbit Erlangga, Jakarta.

Carlo Aldo, 2014. Pengaruh Return On Equity, Dividend Payout Ratio, dan Price To Earning Ratio pada Return Saham.

Djajadi, Yasa, 2018. Analisis Pengaruh Earning Per Share, Debt To Equity Ratio, Asset Growth, dan Risiko Sistematic pada Return Saham.

Gumanti, Tatang Ary, 2011. Manajemen Investasi, Konsep, Teori dan Aplikasi, Edisi pertama, Mitra Wacana Media, Jakarta.

Harjito Agus, 2012 Dasar-dasar Teori Keuangan, Ekonisia, Yogyakarta.

Harjito, D. Agus, Martono, 2011 Manajemen Keuangan, Edisi Kedua, Ekonisasi, Yogyakarta.

Harmono, 2009 Manajemen Keuangan Berbasis Balanced Scorecard, PT. Bumi Aksara, Jakarta.

Husnan Saud, 2009 Dasar-dasar Teori Portofolio \& Analisis Sekuritas Edisi Keempat, UPP STIM YKPN, Yogyakarta.

Margaretha Farah, 2014 Dasar-dasar Manajemen Keuangan, Dian Rakyat, Jakarta.

Musyarofah, Suhadak, Hidayat, 2015, Pengaruh Beta Pasar dan Dividend Payout Ratio Terhadap Return Saham.

Nazir, Ph.d, 2009 Metode Penelitian, Ghalia Indonesia, Jakarta.

Pratisto, Arif, 2010 Statistik menjadi mudah dengan SPSS 17, cetakan kedua, Elex Media, Komputindi, Jakarta.

Puspitadewi, Rahyuda, 2016. Pengaruh DER, ROA, PER dan EVA terhadap Return Saham pada Perusahaan Food and Beverage di BEI.

Santosa Singgih, 2011 Mastering SPSS, PT. Elex Media Komputindo Kompas Gramedia, Jakarta.

Sitanggang, J.P , 2012 Manajemen Keuangan Perusahaan, Mitra Wacana Media, Jakarta.

Sitanggang, J.P , 2013 Manajemen Keuangan Perusahaan Lanjutan, Mitra Wacana Media, Jakarta.

Subramanyam K.R. \& Wild J. John, 2010 Analisis Laporan Keuangan, Salemba Empat, Jakarta.

Tendelilin, Eduardus, 2009 Analisis Investasi dan Manajemen Portofolio, BPFE, Yogyakarta.

Wira Desmon, 2011 Analisis Fundamental Saham, Exceed, Jakarta.

Bisman (Bisnis \& Manajemen): The Journal Of Business and Management 